\title{
First Quarter Hanford Seismic Report for Fiscal Year 1999
}

D. C. Hartshorn

S. P. Reidel

A. C. Rohay

May 1999

Prepared for the U.S. Department of Energy under Contract DE-AC06-76RLO 1830

Pacific Northwest National Laboratory

Richland, Washington 99352 


\section{DISCLAIMER}

This report was prepared as an account of work sponsored by an agency of the United States Government. Neither the United States Government nor any agency thereof, nor any of their employees, make any warranty, express or implied, or assumes any legal liability or responsibility for the accuracy, completeness, or usefulness of any information, apparatus, product, or process disclosed, or represents that its use would not infringe privately owned rights. Reference herein to any specific commercial product, process, or service by trade name, trademark, manufacturer, or otherwise does not necessarily constitute or imply its endorsement, recommendation, or favoring by the United States Government or any agency thereof. The views and opinions of authors expressed herein do not necessarily state or reflect those of the United States Government or any agency thereof. 


\section{DISCLAIMER}

Portions of this document may be illegible in electronic image products. Images are produced from the best available original document. 


\section{Summary}

Hanford Seismic Monitoring provides an uninterrupted collection of high-quality raw and processed seismic data from the Hanford Seismic Network (HSN) for the U.S. Department of Energy and its contractors. The staff also locates and identifies sources of seismic activity and monitors changes in the historical pattern of seismic activity at the Hanford Site. The data are compiled, archived, and published for use by the Hanford Site for waste management, Natural Phenomena Hazards assessments, and engineering design and construction. In addition, the seismic monitoring organization works with the Hanford Site Emergency Services Organization to provide assistance in the event of a significant earthquake on the Hanford Site.

The HSN and the Eastern Washington Regional Network (EWRN) consist of 42 individual sensor sites and 15 radio relay sites maintained by the Hanford Seismic Monitoring staff. The operational rate for the first quarter of FY99 for stations in the HSN was $99.8 \%$. The operational rate for the first quarter of FY99 for stations of the EWRN was 99.8 .

There were 121 triggers during the first quarter of fiscal year 1999. Fourteen triggers were local earthquakes; seven (50\%) were in the Columbia River Basalt Group, no earthquakes occurred in the prebasalt sediments, and seven (50\%) were in the crystalline basement. One earthquake (7\%) occurred near or along the Horn Rapids anticline, seven earthquake (50\%) occurred in a known swarm area, and six earthquakes $(43 \%)$ were random occurrences.

No earthquakes triggered the Hanford Strong Motion Accelerometer during the first quarter of FY99. 



\section{Terms}

$\begin{array}{ll}\text { BWIP } & \text { Basalt Waste Isolation Project } \\ \text { CRBG } & \text { Columbia River Basalt Group } \\ \text { UTC } & \text { Universal Time, Coordinated } \\ \text { DOE } & \text { U.S. Department of Energy } \\ \text { EWRN } & \text { Eastern Washington Regional Network } \\ \text { FY } & \text { Fiscal Year } \\ \text { GPS } & \text { Global Positioning System } \\ \text { HSN } & \text { Hanford Seismic Network } \\ \text { M }_{c} & \text { Coda Length Magnitude } \\ \text { M }_{L} & \text { Local Magnitude } \\ \text { PNNL } & \text { Pacific Northwest National Laboratory } \\ \text { RAW } & \text { Rattlesnake Mountain-Wallula Alignment } \\ \text { USGS } & \text { United States Geological Survey } \\ \text { UW } & \text { University of Washington }\end{array}$




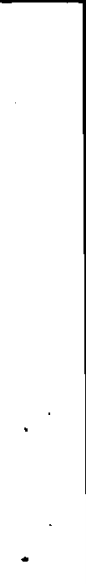




\section{Contents}

Summary

Terms

1.0 Introduction

1.1 History of Seismic Monitoring at Hanford

1.2 Mission

1.3 Documentation.

2.0 Network Operations

2.1 Seismometer Sites.

2.2 Station Maintenance

2.3 Data Acquisition

2.4 Strong Motion Accelerometer Sites................................................................................ 2.2

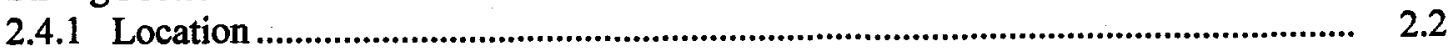

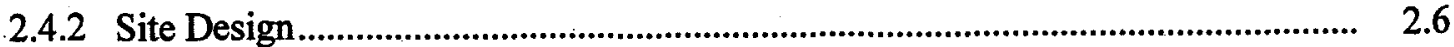

2.4.3 Strong Motion Accelerometer Operations Center .................................................. 2.8

2.4.4 Strong Motion Operational Characteristics ............................................................. 2.8

3.0 Magnitude, Velocity Models, and Quality Factors ............................................................ 3.1

3.1 Coda Length Magnitude ...........................................................................................

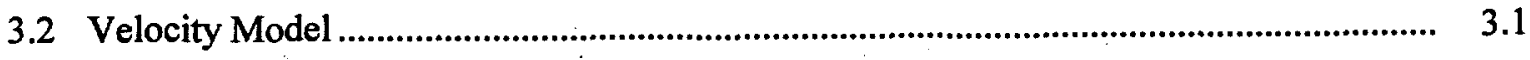

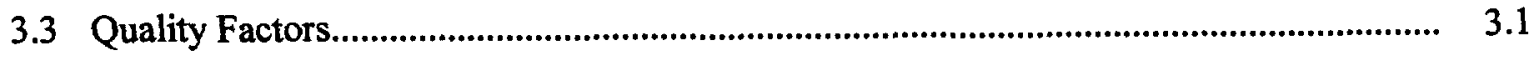

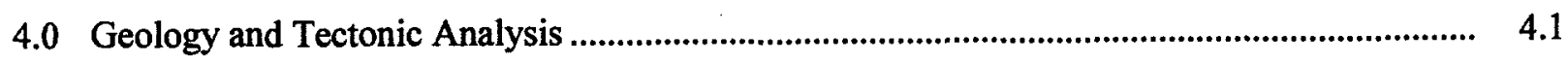

4.1 Earthquake Stratigraphy ........................................................................................ 4.1

4.1.1 Geologic Structure Beneath the Monitored Area.................................................... 4.1

4.1.2 Depth of Earthquakes.............................................................................................. 4.3

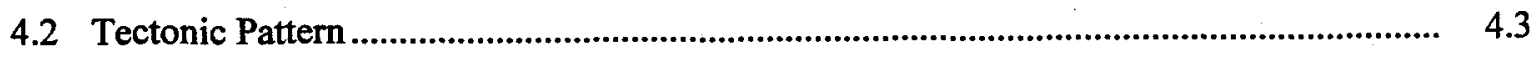

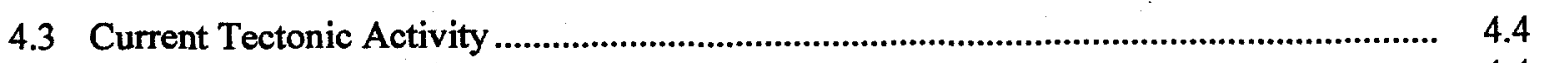

4.3.1 First Quarter of FY 1999 ................................................................................ 4.4

4.3.2 Major Anticlinal Ridges..................................................................................... 4.5

4.3.3 Secondary Geologic Structures........................................................................... 4.5 
4.3.4 Swarm Area Activity ...................................................................................... 4.5

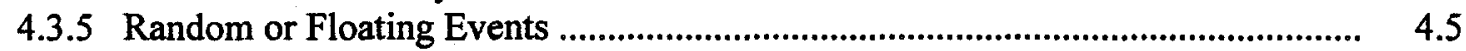

5.0 Strong Motion Accelerometer Operations: May 1997 to September 30, 1997 ........................ 5.1

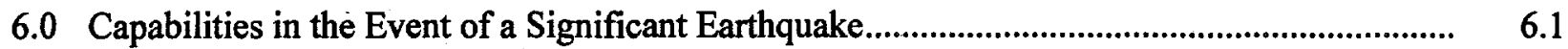

6.1 Use of the SMA Network in the Event of an Earthquake................................................

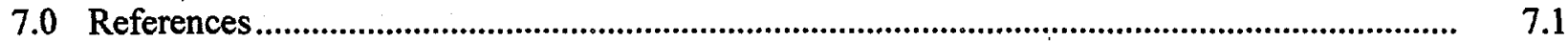




\section{Figures}

1 Locations of Seismograph Stations and Strong Motion Accelerometer Sites in the Hanford Seismic Network

2 Locations of Seismograph Stations in the Eastern Washington Regional Network

3 Schematic Diagram of a Strong Motion Accelerometer Installation

4 Geologic Cross Sections Through the Columbia Basin

5 Locations of All Events Between October 1, 1998 and December 31, 1998

6 All Located Earthquakes Grouped by Quarter for FY99

7 Structural and Tectonic Map of Columbia Basin Showing Major Seismic Source Structures

\section{Tables}

1 Seismic Stations in the Hanford Seismic Network

2 Seismic Stations in the Eastern Washington Regional Network

3 Seismic Channel Operational Time

4 Acquisition System Recorded Triggers

5 Free-Field Strong Motion Accelerometer Sites

6 Instrument Parameters for the Kinemetrics ETNA System in the Hanford Strong Motion Accelerometer Network

7 Seismic Velocities for Columbia Basin Stratigraphy.

8 Local Events from October 1, 1998 Through December 31, 1998

9 Thickness of Stratigraphic Units Across the Monitoring Area

10 Number of Local Earthquakes Occurring in Stratigraphic Units

11 Summary of Earthquake Locations. 


\subsection{Introduction}

\subsection{History of Seismic Monitoring at Hanford}

Seismic monitoring at the Hanford Site was established in 1969 by the United States Geological Survey (USGS) under a contract with the U.S. Atomic Energy Commission. In 1975 the University of Washington (UW) assumed responsibility for the network and subsequently expanded it. In 1979 the Basalt Waste Isolation Program (BWIP) became responsible for collecting seismic data for the Hanford Site as part of site characterization activities. Rockwell Hanford Operations followed by Westinghouse Hanford Company (WHC), operated the local network and were the contract technical advisors for the Eastern Washington Regional Network (EWRN) operated and maintained by the UW. Funding ended for BWIP in December 1988. Seismic Monitoring and responsibility for the University of Washington contract were then transferred to WHC's Environmental Division. Maintenance responsibilities for the EWRN were also assigned to WHC who made major upgrades to EWRN sites. Effective October 1, 1996, Seismic Monitoring was transferred to the Pacific Northwest National Laboratory ( $\mathrm{PNNL}^{1}$ ). Seismic Monitoring is part of PNNL's Applied Geology and Geochemistry Group, Energy Technology Division.

The Hanford Strong Motion Accelerometer network was constructed during 1997 and came on line in May 1997. It operated continuously until September 30,1997 when it was mothballed due to lack of funding. Funding was restored on October 1, 1998 by joint agreement between the U.S. Department of Energy and PNNL. Operation of the free field sites resumed on November 20, 1999.

\subsection{Mission}

The mission of Seismic Monitoring is to provide an uninterrupted collection of high-quality raw seismic data from the HSN located on and around the Hanford Site. These unprocessed data are permanently archived. Hanford Seismic Monitoring also locates and identifies sources of seismic activity, monitors changes in the historical pattern of seismic activity at the Hanford Site, and builds a "local" earthquake database (processed data) that is permanently archived. Local earthquakes are defined as earthquakes that occur between 46 degrees and 47 degrees north latitude and between 119 degrees and 120 degrees west longitude. Data from the EWRN and other seismic networks in the Northwest provide the Seismic Monitoring team with necessary regional input for the seismic hazards analysis at the Hanford Site. The data are used by the Hanford Site contractors for waste management activities, Natural Phenomena Hazards assessments, and engineering design and construction. In addition, the Seismic Monitoring Project works with Hanford Site Emergency Services Organization to provide assistance in the event of an earthquake on the Hanford Site.

\footnotetext{
${ }^{1}$ Pacific Northwest National Laboratory is operated by Battelle Memorial Institute for the U.S. Department of Energy.
} 


\subsection{Documentation}

The Seismic Monitoring Project issues quarterly reports of local activity, an annual catalog of earthquake activity on and near the Hanford Site, and special-interest bulletins on local seismic events.

The annual catalog includes the fourth quarter report for the fiscal year. Hanford Seismic Monitoring also provides information and special reports to other functions as requested. Earthquake information provided in these reports is subject to revisions if new data become available. 


\subsection{Network Operations}

The Hanford Seismic Monitoring network consists of two designs of equipment and sites: seismometer sites and strong motion accelerometer (SMA) sites. Seismometer sites are designed to locate earthquakes on and near the Hanford Site and determine their magnitude and hypocenter location.

The U.S. Department of Energy (DOE) Order 5480.28 requires that facilities or sites that have structures or components in Performance Category 2 with hazardous material, and all Performance Category 3 and 4 facilities shall have instrumentation or other means to detect and record the occurrence and severity of seismic events. In order to comply with DOE Order 5480.28, the Hanford Seismic Monitoring Network seismometer was expanded in 1997 to include strong motion accelerometers to record the ground motion at specific sites. The combined seismometer sites and strong motion accelerometer sites provide the Hanford Site with earthquake information to comply with DOE Order 5480.28. The data from these instruments will be used by the PHMC staff to assess the damage to facilities should a significant earthquake occur at the Hanford Site.

\subsection{Seismometer Sites}

The HSN and the EWRN consists of 42 sensor sites. Most sites are in remote locations and require solar panels and batteries for power. Both networks share sixteen sites; the HSN uses 21 sites (Table 1 and Figure 1) and the EWRN uses 36 sites (Table 2 and Figure 2). The networks have 46 combined data channels because Gable Butte and Royal City are three-component sites, each consisting of one vertical, one north-south horizontal, and one east-west horizontal data channel. Both networks use 15 additional telemetry relay sites. All station data links pass through at least one of these relay sites. Some data links transit as many as three relay sites. The last section of the data link for all channels is commercial telephone lines. Three to eight channels are multiplexed per telephone line going to the Seismic Monitoring office in the 337 building.

\subsection{Station Maintenance}

The HSN's maintenance records for the seismic sensor and relay sites are filed in the Hanford Seismic Monitoring office. Periods of major outages are addressed in this report. Table 3 shows the operational percentage time for each network.

\subsection{Data Acquisition}

Data from seismometer sites are recorded at the Hanford Seismic Monitoring office. The Hanford Seismic Network is divided into subnetworks using weighted factors to minimize false triggers but still allow very small seismic events to be recorded. All events that trigger the acquisition computer are analyzed for complex events. Complex events are more than one earthquake or an earthquake contained within a record triggered by another source. Table 4 shows the number of each event type recorded during the fourth quarter. 
Table 1. Seismic Stations in the Hanford Seismic Network

\begin{tabular}{|c|c|c|c|c|}
\hline Station & $\begin{array}{c}\text { Latitude } \\
\text { Deg.Min.N }\end{array}$ & $\begin{array}{l}\text { Longitude } \\
\text { Deg.Min.W }\end{array}$ & Elevation (m) & Station Name \\
\hline BEN & $46 \mathrm{~N} 31.13$ & $119 \mathrm{~W} 43.02$ & 340 & Benson Ranch \\
\hline$\overline{B R V}$ & $46 \mathrm{~N} 49.12$ & 119W59.47 & 920 & Black Rock Valley \\
\hline BVW & $46 \mathrm{~N} 48.66$ & $119 W 52.99$ & 670 & Beverly \\
\hline CRF & $46 \mathrm{~N} 49.50$ & $119 W 23.22$ & 189 & Corfu \\
\hline ET3 & 46 N34.64 & $118 W 56.25$ & 286 & Eltopia Three \\
\hline *FHE & $46 \mathrm{~N} 57.13$ & $119 W 29.92$ & 463 & Frenchman Hills East \\
\hline${ }^{*} \mathrm{GBB}$ & $46 \mathrm{~N} 36.49$ & $119 W 37.62$ & 177 & Gable Butte \\
\hline GBL & $46 \mathrm{~N} 35.92$ & $119 W 27.58$ & 330 & Gable Mountain \\
\hline $\mathrm{H} 2 \mathrm{O}$ & $46 \mathrm{~N} 23.75$ & $119 W 25.38$ & 158 & Water \\
\hline LOC & $46 \mathrm{~N} 43.02$ & $119 \mathrm{~W} 25.85$ & 210 & Locke Island \\
\hline MDW & $46 \mathrm{~N} 36.79$ & $119 W 45.66$ & 330 & Midway \\
\hline MJ2 & $46 \mathrm{~N} 33.45$ & $119 W 21.54$ & 146 & May Junction Two \\
\hline OT3 & $46 \mathrm{~N} 40.14$ & $119 W 13.98$ & 322 & Othello Three \\
\hline PRO & $46 \mathrm{~N} 12.73$ & $119 \mathrm{~W} 41.15$ & 550 & Prosser \\
\hline RED & $46 \mathrm{~N} 17.92$ & $119 W 26.30$ & 366 & Red Mountain \\
\hline RSW & $46 \mathrm{~N} 23.67$ & $119 W 35.48$ & 1,045 & Rattlesnake Mountain \\
\hline SNI & $46 \mathrm{~N} 27.85$ & $119 W 39.60$ & 312 & Snively Ranch \\
\hline WA2 & $46 \mathrm{~N} 45.32$ & 119 W33.94 & 244 & Wahluke Slope \\
\hline WG4 & $46 \mathrm{~N} 01.85$ & 118 W51.34 & 511 & Wallula Gap Four \\
\hline WIW & $46 \mathrm{~N} 25.76$ & $119 W 17.26$ & 128 & Wooded Island \\
\hline WRD & $46 \mathrm{~N} 58.20$ & $119 W 08.69$ & 375 & Warden \\
\hline
\end{tabular}

\subsection{Strong Motion Accelerometer Sites}

\subsubsection{Location}

The Hanford Strong Motion Accelerometer (SMA) network consists of five free-field SMA Sites (Figure 1) and one SMA housed in the 337 Building (Table 5). There is one free-field SMA located in each of the 200 Separations Areas, one adjacent to the K-Basins in $100 \mathrm{~K}$ Area, one adjacent to the 400 Area where the Fast Flux Test Reactor is located and one at the south end of the 300 Area. 


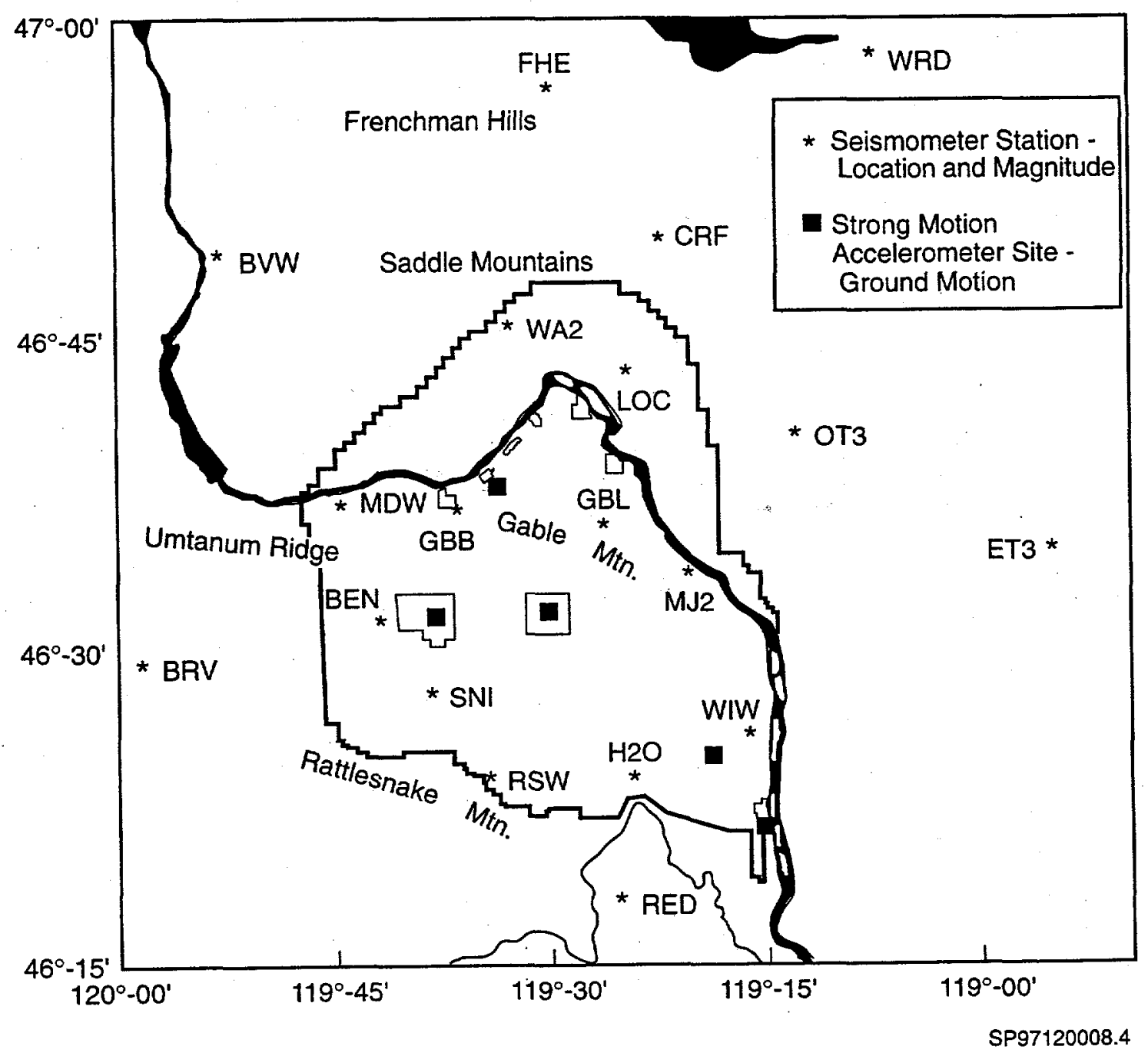

Figure 1. Locations of Seismograph Stations and Strong Motion Accelerometer Sites in the Hanford Seismic Network (See Table 1 for description of locations.)

The instrumentation locations were chosen based on two criteria (Moore and Reidel 1996):

1) instruments should be located in areas having the highest densities of people; and 2) instruments should be located in areas having hazardous facilities. Some of the highest concentrations of employees at Hanford are 200 East and West Areas, $100 \mathrm{~K}$ Area, the Fast Flux Test Facility (400 Area) and the 300 Areas. The 200 Areas are where all high-level radioactive waste from past processing of fuel rods has been stored in single-shell and double-shell tanks. In addition the Canister Storage Facility that will hold encapsulated spent fuel rods is being constructed in 200 East Area. The $100 \mathrm{~K}$ Area presently contains the $\mathrm{K}$ Basins where all spent fuel rods from the $\mathrm{N}$ Reactor are stored prior to encapsulation. The Cold Vacuum Drying Facility is presently being constructed in the $100 \mathrm{~K}$ Area to encapsulate spent fuel rods from the K Basins prior to shipment to the Canister Storage Building in 200 East Area. 
Table 2. Seismic Stations in the Eastern Washington Regional Network

\begin{tabular}{|c|c|c|c|c|}
\hline \multicolumn{5}{|c|}{$\begin{array}{l}\text { The first column is the three-letter seismic station designator. The latitude and longitude, elevation above sea level } \\
\text { in meters; and the full station name follow this. An asterisk before the three-letter designator means it is a three- } \\
\text { component station. The locations of the stations are all in Washington unless otherwise indicated; locations were } \\
\text { determined from a Global Positioning Satellite System (GPS). }\end{array}$} \\
\hline Station & $\begin{array}{c}\text { Latitude } \\
\text { Deg.Min.N. }\end{array}$ & $\begin{array}{c}\text { Longitude } \\
\text { Deg.Min.W. } \\
\end{array}$ & Elevation (m) & Station Name \\
\hline BRV & $46 \mathrm{~N} 29.12$ & $119 W 59.47$ & 920 & Black Rock Valley \\
\hline BVW & $46 \mathrm{~N} 48.66$ & $119 W 52.99$ & 670 & Beverly Washington \\
\hline CBS & $47 N 48.26$ & 120W02.50 & 1,067 & Chelan Butte, South \\
\hline CRF & $46 \mathrm{~N} 49.50$ & $119 \mathrm{~W} 23.22$ & 189 & Corfu \\
\hline DPW & $47 \mathrm{~N} 52.25$ & $118 \mathrm{~W} 12.17$ & 892 & Davenport \\
\hline DY2 & $47 N 59.11$ & $119 W 46.28$ & 890 & Dyer Hill Two \\
\hline ELL & $46 \mathrm{~N} 54.58$ & 120 W33.98 & 789 & Ellensburg \\
\hline EPH & $47 \mathrm{~N} 21.38$ & $119 W 35.76$ & 661 & Ephrata \\
\hline ET3 & $46 \mathrm{~N} 34.64$ & $118 W 56.25$ & 286 & Eltopia Three \\
\hline ETW & $47 \mathrm{~N} 36.26$ & 120W19.94 & 1,477 & Entiat \\
\hline *FHE & $46 \mathrm{~N} 57.13$ & $119 W 29.92$ & 463 & Frenchman Hills East \\
\hline${ }^{*} \mathrm{GBL}$ & $46 \mathrm{~N} 35.92$ & $119 W 27.58$ & 330 & Gable Mountain \\
\hline LNO & $45 \mathrm{~N} 52.31$ & $118 \mathrm{~W} 17.11$ & 771 & Lincton Mountain, Oregon \\
\hline LOC & $46 \mathrm{~N} 43.02$ & $119 W 25.85$ & 210 & Locke Island \\
\hline MDW & $46 \mathrm{~N} 36.79$ & $119 \mathrm{~W} 45.66$ & 330 & Midway \\
\hline MJ2 & $46 \mathrm{~N} 33.45$ & $119 W 21.54$ & 146 & May Junction Two \\
\hline MOX & $46 \mathrm{~N} 34.64$ & $120 W 17.89$ & 501 & Moxee City \\
\hline NAC & $46 \mathrm{~N} 43.99$ & 120W49.42 & 728 & Naches \\
\hline NEL & $48 \mathrm{~N} 04.21$ & $120 W 20.41$ & 1,500 & Nelson Butte \\
\hline OD2 & $47 \mathrm{~N} 23.26$ & $118 W 42.58$ & 553 & Odessa Two \\
\hline OT3 & $46 \mathrm{~N} 40.14$ & 119W13.98 & 322 & Othello Three \\
\hline PAT & $45 \mathrm{~N} 52.92$ & $119 W 45.14$ & 262 & Paterson \\
\hline PRO & $46 \mathrm{~N} 12.73$ & $119 \mathrm{~W} 41.15$ & 550 & Prosser \\
\hline RSW & $46 \mathrm{~N} 23.67$ & $119 W 35.48$ & 1,045 & Rattlesnake Mountain \\
\hline SAW & $47 \mathrm{~N} 42.10$ & $119 W 24.03$ & 701 & St. Andrews \\
\hline SNI & $46 \mathrm{~N} 27.85$ & 119W39.60 & 312 & Snively Ranch \\
\hline TBM & $47 \mathrm{~N} 10.20$ & $120 W 35.88$ & 1,006 & Table Mountain \\
\hline TRW & $46 \mathrm{~N} 17.32$ & $120 \mathrm{~W} 32.31$ & 723 & Toppenish Ridge \\
\hline TWW & $47 \mathrm{~N} 08.29$ & 120W52.10 & 1,027 & Teanaway \\
\hline VT2 & $46 \mathrm{~N} 58.04$ & 119W58.95 & 1,270 & Vantage Two \\
\hline WA2 & $46 \mathrm{~N} 45.32$ & $119 W 33.94$ & 244 & Wahluke Slope Two \\
\hline WAT & $47 \mathrm{~N} 41.92$ & 119W57.24 & 821 & Waterville \\
\hline WG4 & $4 \curvearrowleft \mathrm{N} 01.85$ & $118 W 51.34$ & 511 & Wallula Gap Four \\
\hline WIW & $46 \mathrm{~N} 25.76$ & $119 W 17.26$ & 128 & Wooded Island \\
\hline WRD & $46 \mathrm{~N} 58.20$ & 119W08.69 & 375 & Warden \\
\hline YA2 & $46 \mathrm{~N} 31.60$ & $120 \mathrm{~W} 31.80$ & 652 & Yakima Two \\
\hline
\end{tabular}




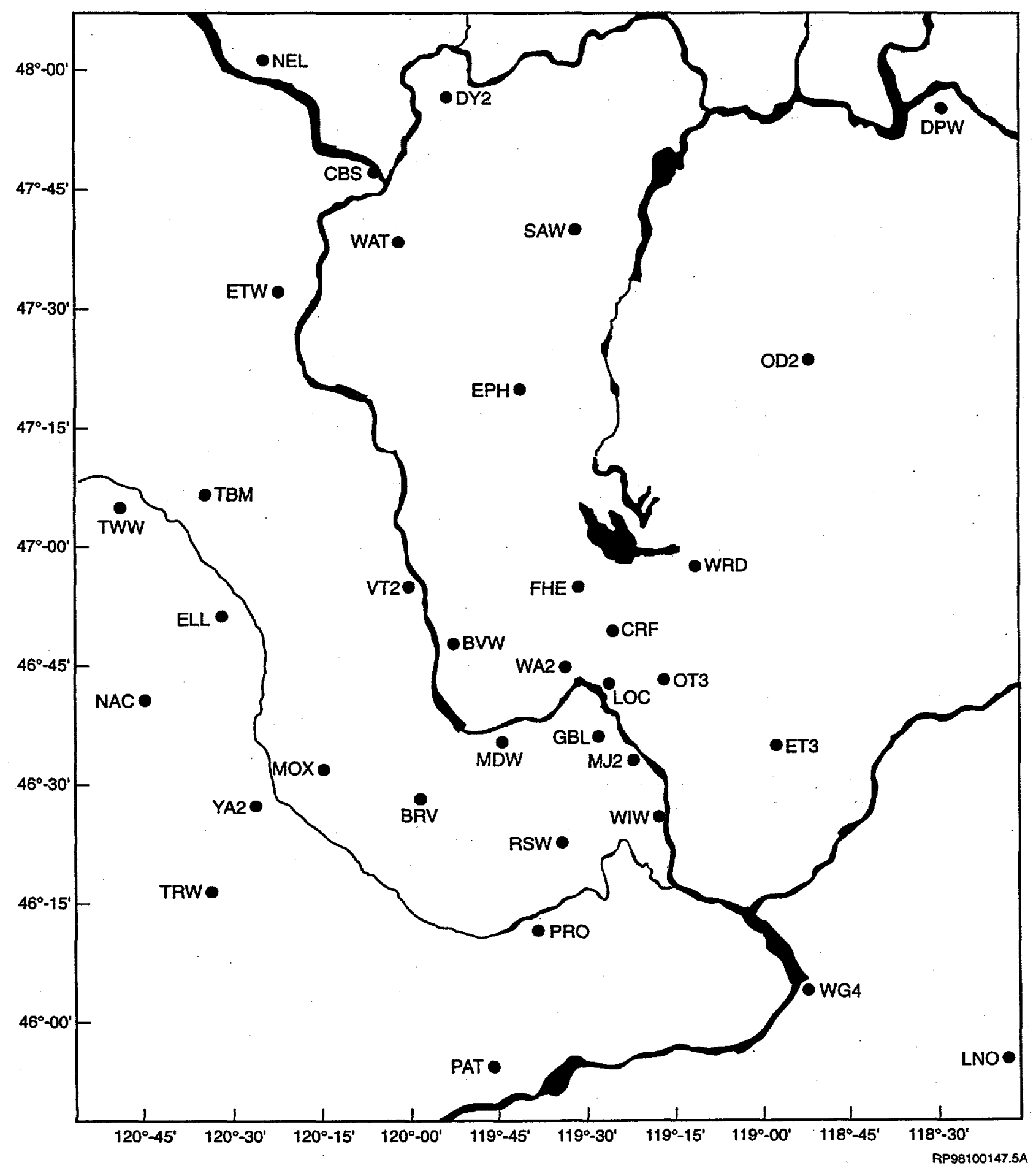

Figure 2. Locations of Seismograph Stations in the Eastern Washington Regional Network (See Table 2 for location descriptions.) 
Table 3. Seismic Channel Operational Time (\%)

\begin{tabular}{|l|l|c|c|c|c|}
\hline Network & First Quarter & Second Quarter & Third Quarter & Fourth Quarter & FY99 \\
\hline \hline Hanford & $99.84 \%$ & - & - & - & $99.84 \%$ \\
\hline Regional & $99.76 \%$ & - & - & - & $99.76 \%$ \\
\hline
\end{tabular}

Table 4. Acquisition System Recorded Triggers

\begin{tabular}{|c|c|c|c|c|c|c|}
\hline Event Type & $\begin{array}{l}\text { First } \\
\text { Quarter }\end{array}$ & $\begin{array}{l}\text { Second } \\
\text { Quarter }\end{array}$ & $\begin{array}{l}\text { Third } \\
\text { Quarter }\end{array}$ & $\begin{array}{l}\text { Fourth } \\
\text { Quarter }\end{array}$ & FY99 & Remarks \\
\hline Local & 14 & - & - & - & 14 & $\begin{array}{l}\text { Earthquakes within the } 46-47 \text { degrees north } \\
\text { latitude and } 119-120 \text { degrees west longitude }\end{array}$ \\
\hline Regional & 39 & - & - & - & 39 & $\begin{array}{l}\text { Earthquakes surrounding Hanford within the } \\
\text { range of } 80 \text { to } 500 \text { kilometers }\end{array}$ \\
\hline Teleseism & 43 & - & - & - & 43 & $\begin{array}{l}\text { Earthquakes from around the world greater } \\
\text { than } 500 \mathrm{~km} \text { in distance. }\end{array}$ \\
\hline Artillery & 12 & - & - & - & 12 & $\begin{array}{l}\text { Acoustical shock waves from artillery, thun- } \\
\text { der, and high-performance aircraft sonic } \\
\text { booms. }\end{array}$ \\
\hline Explosion & 3 & - & - & - & 3 & Confirmed blast, usually in borrow pits. \\
\hline $\begin{array}{l}\text { Probable } \\
\text { Explosion }\end{array}$ & 0 & - & - & - & 0 & $\begin{array}{l}\text { Believed to be a blast because of wave } \\
\text { characteristics but cannot be confirmed. }\end{array}$ \\
\hline Noise & 10 & & & & 10 & $\begin{array}{l}\text { Triggers caused by data line circuits, } \\
\text { lightning, maintenance triggers during } \\
\text { system testing, high winds, coincidental } \\
\text { noise at multiple sites within a trigger } \\
\text { subnet, etc. }\end{array}$ \\
\hline $\begin{array}{l}\text { Total } \\
\text { Triggers }\end{array}$ & 121 & & & & 121 & \\
\hline
\end{tabular}

\subsubsection{Site Design}

This section describes the designs of the strong motion accelerometer sites as of October 1, 1998. All sites are being upgraded during FY99 to insure continuous operation and low maintenance.

All free-field Strong Motion Accelerometer consist of two 30-gallon drums set in the ground such that the base of the drum is about 1 meter below the surface. One drum houses only the SMA; the other drum houses the electronics and communications equipment. A distance of 40 to 85 inches separates the drum containing the electronics and communications equipment from the SMA drum; a sealed conduit connects the two drums.

The SMA instruments are three-component units consisting of one vertical, one north-south horizontal, and one east-west horizontal data channel. The instruments in use are the ETNA system of 
Table 5. Free-Field Strong Motion Accelerometer Sites

\begin{tabular}{|c|c|c|c|c|}
\hline Site & $\begin{array}{l}\text { Site } \\
\text { ID }\end{array}$ & Location & $\begin{array}{l}\text { Latitude } \\
\text { Longitude } \\
\text { Elevation }\end{array}$ & Design \\
\hline $100 \mathrm{~K}$ Area & H1K & $\begin{array}{l}\text { South of K Basins outside } 100 \\
\text { Area fence lines. }\end{array}$ & $\begin{array}{l}46^{\circ} 38.51^{\prime} \\
119^{\circ} \\
35.53^{\prime} \\
152 \mathrm{~m}\end{array}$ & $\begin{array}{l}\text { One free-field Kinemetrics ETNA } \\
\text { Model SMA housed in a ground } \\
\text { vault. }\end{array}$ \\
\hline $\begin{array}{l}200 \text { East } \\
\text { Area }\end{array}$ & $\mathrm{H} 2 \mathrm{E}$ & $\begin{array}{l}\text { East of B Plant; north of } 7 \text { th } \\
\text { street and east of Baltimore Ave. }\end{array}$ & $\begin{array}{l}46^{\circ} 33.58^{\prime} \\
119^{\circ} \\
32.00^{\prime} \\
210 \mathrm{~m}\end{array}$ & $\begin{array}{l}\text { One free-field Kinemetrics ETNA } \\
\text { Model SMA housed in ground } \\
\text { vault. }\end{array}$ \\
\hline $\begin{array}{l}200 \text { West } \\
\text { Area }\end{array}$ & $\mathrm{H} 2 \mathrm{~W}$ & $\begin{array}{l}\text { Northeast of Plutonium Finishing } \\
\text { Plant (PFP); north of 19th street } \\
\text { and east of Camden Ave. }\end{array}$ & $\begin{array}{l}46^{\circ} 33.23^{\prime} \\
119^{\circ} \\
37.51^{\prime} \\
206 \mathrm{~m}\end{array}$ & $\begin{array}{l}\text { One free-field Kinemetrics ETNA } \\
\text { Model SMA housed in ground } \\
\text { vault. }\end{array}$ \\
\hline 300 Area & $\mathrm{H} 3 \mathrm{~A}$ & $\begin{array}{l}\text { South end of } 300 \text { Area inside } \\
\text { fence lines. (NE 1/4, SW 1/4, } \\
\text { Sec. 11, T10N, R28E). }\end{array}$ & $\begin{array}{l}46^{\circ} 21.83^{\prime} \\
119^{\circ} \\
16.55^{\prime} \\
119 \mathrm{~m} \\
\end{array}$ & $\begin{array}{l}\text { One free-field Kinemetrics ETNA } \\
\text { Model SMA housed in ground } \\
\text { vault. }\end{array}$ \\
\hline 400 Area & H4A & $\begin{array}{l}500 \text { feet from fence line on east } \\
\text { side of facility and north of } \\
\text { parking area). }\end{array}$ & $\begin{array}{l}46^{\circ} 26.13^{\prime} \\
119^{\circ} \\
21.30^{\prime} \\
171 \mathrm{~m}\end{array}$ & $\begin{array}{l}\text { One free-field Kinemetrics ETNA } \\
\text { Model SMA housed in ground } \\
\text { vault. }\end{array}$ \\
\hline 337 Building & H3B & $\begin{array}{l}\text { Office of Seismic Monitoring, } \\
\text { Room } 176 .\end{array}$ & $\begin{array}{l}46^{\circ} 22^{\prime} \\
119^{\circ} 17 \\
140 \mathrm{~m}\end{array}$ & $\begin{array}{l}\text { One Kinemetrics ETNA Model } \\
\text { SMA attached to concrete floor. }\end{array}$ \\
\hline
\end{tabular}

Kinemetrics, Inc. Instrument specifications are summarized in Table 6. In addition to the threecomponent SMA's, each ETNA SMA unit contains a computer, Global Positioning System receiver and a modem (Figure 3). These systems are housed in a watertight box.

Two 100 amp-hour batteries that are housed in the equipment and communications drum (Figure 3) power the SMAs. The batteries are charged currently by two solar panels; a regulator is located between the solar panels and the batteries. All sites are being upgraded to four solar panels.

The communication link between the SMAs and the data analysis computer system housed in the Office of Seismic Monitoring is via a cellular telephone/modem connection. The built-in modem in the SMA allows the system to use a cellular telephone to call an accelerometer or for the accelerometer to call out in the event it is triggered. The system is being upgraded to allow pager notification in the event of a system trigger.

The SMAs have an internal Global Positioning System (GPS) receiver used principally to link it to the National Bureau of Standards timing system. The GPS is internally activated approximately every 4 hours and checks the location of the instrument and the time. Any differences between the internal 


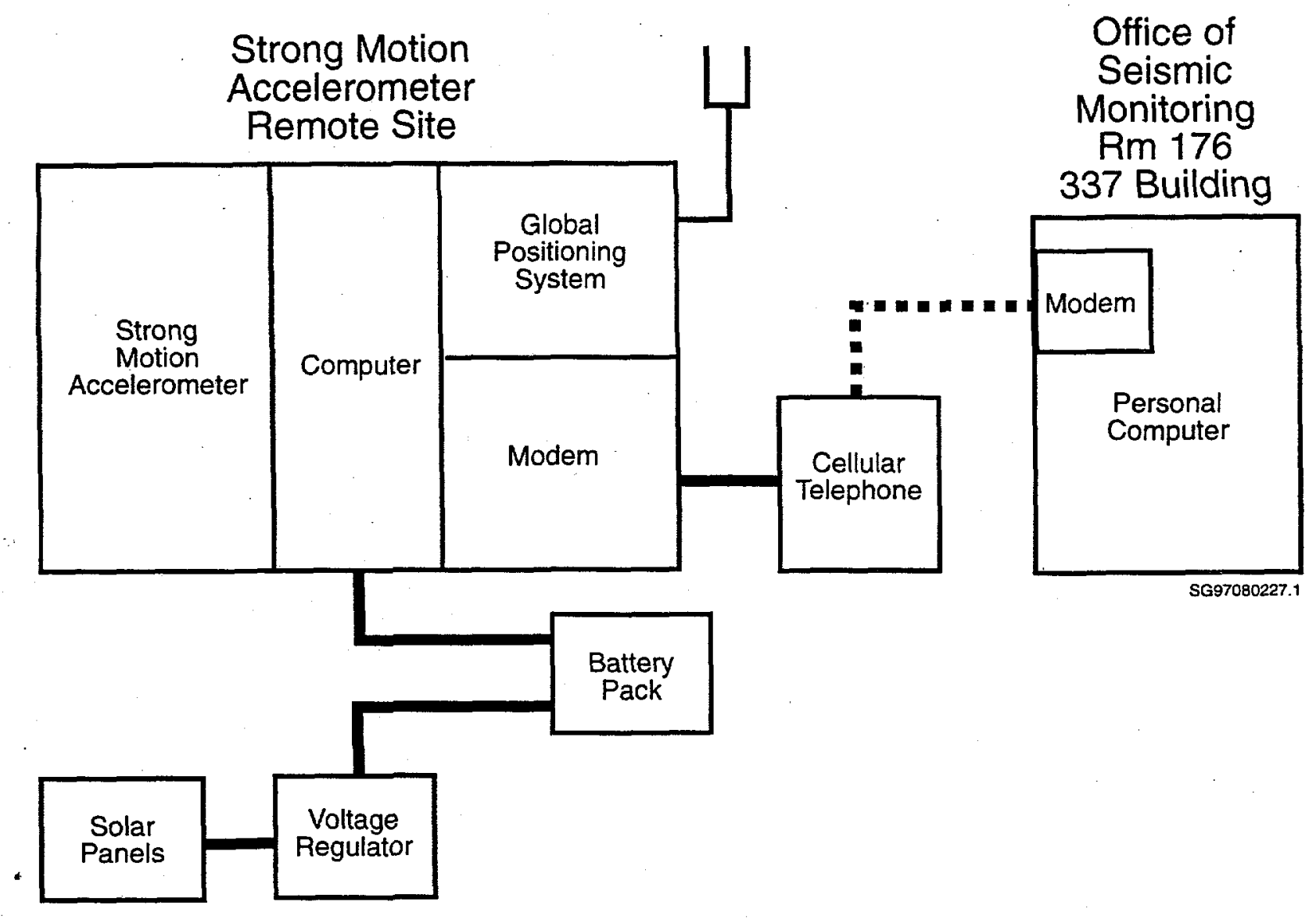

Figure 3. Schematic Diagram of a Strong Motion Accelerometer Installation

clock and the GPS time are recorded and saved by the SMA. Any corrections to the internal timing are made automatically. After the first 6 months of operation in 1997, the greatest difference recorded is approximately 4 milliseconds.

\subsubsection{Strong Motion Accelerometer Operations Center}

The combined operations, data recording and interpretation, and maintenance facility is located in the Office of Seismic Monitoring and is operated by the PNNL Seismic Monitoring Team. This organization provides an area and point of contact for facility Emergency Response and Safety Personnel and facility managers to receive information in the event of an earthquake.

\subsubsection{Strong Motion Operational Characteristics}

The signals from the three accelerometer channels at each site are digitized with a 24-bit digitizer and temporarily stored in a memory buffer. The sampling rate of the digitizer is set to $200 \mathrm{~Hz}$. The three 
Table 6. Instrument Parameters for the Kinemetrics ETNA System in the Hanford Strong Motion Accelerometer Network

\begin{tabular}{||l|l||}
\hline \multicolumn{1}{|c|}{ Parameter } & \multicolumn{1}{|c|}{ Value or Range } \\
\hline \hline Sensor & $\begin{array}{l}\text { Tri-axial Force Balance Accelerometer orthogonally } \\
\text { oriented with internal standard }\end{array}$ \\
\hline Type & $2-2.5 \mathrm{~g}^{(\mathbf{a})}$ \\
\hline Full-Scale & $50 \pm \mathrm{Hz}$ range \\
\hline Natural Frequency & approximately $70 \%$ critical $^{(\mathrm{a})}$ \\
\hline Damping & \\
\hline Data Acquisition & 3 \\
\hline Number of Channels & 18 -bit resolution @ 200 samples/second \\
\hline Sample Rate & Real-time, RS-232 Output Stream \\
\hline Digital Output & \\
\hline Seismic Trigger & $0.1-12.5 \mathrm{~Hz}$ \\
\hline Filter & $0.04 \% \mathrm{~g}$ to $0.20 \% \mathrm{~g} \mathrm{~g}^{(\mathrm{b})}$ \\
\hline Trigger level & $4.00 \% \mathrm{~g}$ \\
\hline Alarm (call-out) Threshold & $10 \mathrm{sec}$ \\
\hline Pre-event Memory & $40 \mathrm{sec}$ \\
\hline Post-event Time & \\
\hline (a) Setting is dependent on instrument calibration. \\
(b) See Section 3 for discussion of trigger thresholds.
\end{tabular}

channels are monitored for signals that equal or exceed a programmable trigger threshold. When one accelerometer channel is triggered, the other channels automatically record. The nominal threshold used is $0.05 \%$ of the full-scale range of $2.0 \mathrm{~g}$ ( $\mathrm{g}$ is the acceleration of gravity, $9.8 \mathrm{~m} / \mathrm{s}^{2}$ or $32 \mathrm{ft} / \mathrm{s}^{2}$ ) or $0.001 \mathrm{~g}$. Threshold trigger levels are being adjusted to trigger infrequently on the noise sources (e.g., vehicles, sonic booms) near each site. This will provide ground motion data for smaller, non-damaging earthquakes that can be useful in estimating the ground motion expected from larger earthquakes, and to confirm correct operation of the instruments by analyzing the smaller-amplitude triggers. The recorders store information for 10 seconds before the trigger threshold is exceeded and for 40 seconds after the trigger ceases to be exceeded.

The SMA network is designed to transmit the data to the Hanford Seismic Recording Center at the Office of Seismic Monitoring or to be remotely accessed with a PC and modem. In addition, all SMAs can be accessed in the field where the data can be downloaded and interpreted. 


\subsection{Magnitude, Velocity Models, and Quality Factors}

\subsection{Coda Length Magnitude}

Coda-length magnitude $\left(\mathrm{M}_{c}\right)$, an estimate of local magnitude $\left(\mathrm{M}_{\mathrm{L}}\right)$ (Richter 1958), is calculated using the coda-length/magnitude relationship determined for Washington by Crosson (1972).

\subsection{Velocity Model}

The program XPED uses the velocities and layer depths given in Table 7. XPED was developed at the UW and the velocity model used in XPED is based on Rohay et al. (1985). XPED is an interactive earthquake seismogram display program used to analyze seismic events.

\subsection{Quality Factors (Q)}

XPED assigns a two-letter Quality factor (Table 8) that indicates the general reliability of the solution ( $\mathbf{A}$ is best quality, $\mathbf{D}$ is worst). Similar quality factors are used by the USGS for events located with the computer program HYPO71. The first letter of the quality code is a measure of the hypocenter quality based primarily on travel time residuals. For example: Quality A requires a root-mean-square residual (RMS) less than 0.15 seconds while a RMS of 0.5 seconds or more is $D$ quality (other estimates of the location uncertainty also affect this quality parameter). The second letter of the quality code is related to the spatial distribution of stations that contribute to the event's location, including the number of stations (NS), the number of p-wave and s-wave phases (NP), the largest gap in event-station azimuth distribution (GAP), and the closest distance from the epicenter to a station (DMIN). Quality A requires a solution with NP $>8, G A P<90^{\circ}$, and DMIN $<5 \mathrm{~km}$ (or the hypocenter depth if it is greater than $5 \mathrm{~km}$ ). If $\mathbf{N P} \leq 5, \mathbf{G A P}>180^{\circ}$, or DMIN $>50 \mathrm{~km}$, the solution is assigned Quality $\mathbf{D}$.

Table 7. Seismic Velocities for Columbia Basin Stratigraphy. (See Rohay et al. 1985.)

\begin{tabular}{|c|l|c|}
\hline $\begin{array}{c}\text { Depth to Top of Velocity } \\
\text { Layer }(\mathrm{km})\end{array}$ & \multicolumn{1}{|c|}{ Stratigraphy } & $\begin{array}{c}\text { Velocity } \\
(\mathrm{km} / \mathrm{sec})\end{array}$ \\
\hline \hline 0.0 & $\begin{array}{l}\text { Saddle Mountains and Wanapum Basalts and intercalated } \\
\text { Ellensburg Formation }\end{array}$ & 3.7 \\
\hline 0.4 & Grande Ronde Basalt and pre-basalt sediments & 5.2 \\
\hline 8.5 & Crystalline Basement, Layer 1 & 6.1 \\
\hline 13.0 & Crystalline Basement, Layer 2 & 6.4 \\
\hline 23.0 & Sub-basement & 7.1 \\
\hline 38.0 & Mantle & 7.9 \\
\hline
\end{tabular}


Table 8. Local Events from October 1, 1998 Through December 31, 1998

\begin{tabular}{|c|c|c|c|c|c|c|c|c|c|c|c|c|c|}
\hline Event ID & Date & Time & Latitude & Longitude & Depth & MAG & NS/NP & GAP & DMIN & RMS & $\mathrm{Q}$ & Type & Location \\
\hline 98100916092 & $98 / 10 / 09$ & $6: 09: 26.94$ & $46 \mathrm{~N} 15.16$ & $119 W 21.95$ & 0.04 & 2.3 & $14 / 19$ & 217 & 7 & 0.08 & $\mathrm{AD}$ & $\mathrm{X}$ & $\begin{array}{l}6.7 \mathrm{~km} \text { WSW of Richland, } \\
\text { WA }\end{array}$ \\
\hline 98101601453 & $8 / 10 / 16$ & $: 47: 42.76$ & $46 \mathrm{~N} 21.14$ & $119 W 23.19$ & 1.61 & 0.1 & $4 / 07$ & 171 & 5 & 0.09 & $A D$ & & $10.5 \mathrm{~km} \mathrm{SSW}$ of FFTF \\
\hline 98103021542 & $98 / 10 / 30$ & 21:54:21.39 & $46 \mathrm{~N} 28.19$ & $119 W 05.34$ & 11.61 & 0.6 & $10 / 14$ & 190 & 15 & 0.08 & $A D$ & & $21 \mathrm{~km}$ east of FFTF \\
\hline 98111623560 & $98 / 11 / 16$ & 23:56:01.77 & $46 \mathrm{~N} 12.11$ & $119 W 48.35$ & 19.19 & 0.9 & $13 / 18$ & 266 & 27 & 0.06 & $A D$ & & $39 \mathrm{~km} \mathrm{SSW}$ of $200 \mathrm{~W}$ area \\
\hline 98111700013 & $98 / 11 / 17$ & $00: 01: 33.71$ & $46 \mathrm{~N} 13.27$ & $119 W 47.43$ & 21.49 & 1.2 & $9 / 14$ & 273 & 24 & 0.06 & $\mathrm{AD}$ & & $37 \mathrm{~km} \mathrm{SSW}$ of $200 \mathrm{~W}$ area \\
\hline 98111702504 & $98 / 11 / 17$ & 02:50:49.13 & $46 \mathrm{~N} 09.96$ & $119 \mathrm{~W} 49.60$ & 17.78 & 1.4 & $15 / 20$ & 275 & 12 & 0.06 & $\mathrm{AD}$ & & $43.5 \mathrm{~km}$ of SSW of $200 \mathrm{~W}$ \\
\hline 98111702561 & $98 / 11 / 17$ & 02:56:09.49 & $46 \mathrm{~N} 11.21$ & $119 W 47.43$ & 18.19 & 1.0 & $11 / 17$ & 292 & 8 & 0.06 & $A D$ & & $40 \mathrm{~km} \mathrm{SSW}$ of $200 \mathrm{~W}$ \\
\hline 98112203194 & $98 / 11 / 22$ & 03:19:43.49 & $46 \mathrm{~N} 41.17$ & $119 W 17.22$ & 4.37 & 0.6 & $13 / 19$ & 95 & 4 & 0.04 & $\mathrm{AB}$ & & $19 \mathrm{~km}$ east of $100 \mathrm{~N}$ area \\
\hline 98112203344 & $98 / 11 / 22$ & 03:34:46.78 & $46 \mathrm{~N} 40.96$ & $119 W 17.46$ & 4.62 & 0.8 & $15 / 22$ & 89 & 4 & 0.08 & AA & & $20 \mathrm{~km} \mathrm{E}$ of $100 \mathrm{~N}$ \\
\hline 98112203351 & $98 / 11 / 22$ & 03:34:72.40 & $46 \mathrm{~N} 41.01$ & $119 \mathrm{~W} 17.21$ & 3.72 & 0.3 & $14 / 17$ & 137 & 4 & 0.06 & $\mathrm{AC}$ & & $21 \mathrm{~km}$ east of $100 \mathrm{~N}$ \\
\hline 98112203384 & $98 / 11 / 22$ & 03:38:45.90 & $46 \mathrm{~N} 40.95$ & $119 W 16.81$ & 4.68 & 0.8 & $15 / 21$ & 94 & 3 & 0.08 & $A B$ & & $21 \mathrm{~km}$ east of $100 \mathrm{~N}$ \\
\hline 98112203392 & $98 / 11 / 22$ & $03: 38: 84.47$ & $46 N 41.34$ & $119 W 16.99$ & 6.61 & -0.6 & $5 / 09$ & 147 & 4 & 0.02 & $\mathrm{AD}$ & & $20 \mathrm{~km}$ east of $100 \mathrm{~N}$ \\
\hline 98112413312 & $98 / 11 / 24$ & $13: 31: 19.90$ & $46 \mathrm{~N} 13.92$ & $119 W 48.70$ & 12.76 & 0.0 & $4 / 05$ & 329 & 24 & 0.06 & $\mathrm{BD}$ & & $36 \mathrm{~km} \mathrm{SSW}$ of $200 \mathrm{~W}$ area \\
\hline 98112518342 & $98 / 11 / 25$ & $18: 34: 21.75$ & $46 \mathrm{~N} 40.71$ & $119 W 23.76$ & 24.99 & 0.5 & $5 / 08$ & 262 & 15 & 0.02 & $\mathrm{AD}$ & & $12 \mathrm{~km}$ east of $100 \mathrm{~N}$ \\
\hline 98120312550 & $98 / 12 / 03$ & 12:55:07.92 & $46 \mathrm{~N} 50.21$ & $119 W 17.70$ & 1.57 & 0.9 & $15 / 24$ & 138 & 7 & 0.04 & $\mathrm{AC}$ & & $27 \mathrm{~km} \mathrm{NE}$ of $100 \mathrm{~N}$ \\
\hline
\end{tabular}




\section{Explanation of Table 8.}

EVENT ID: The analysis program XPED creates the identification number. XPED uses the year, month, day and time to create a unique number for each event.

DATE: The year and day of the year in Universal Time Coordinated (UTC). UTC is used throughout this report unless otherwise indicated.

TIME: The origin time of the earthquake given in UTC. To covert UTC to Pacific Standard Time, subtract eight hours; to Pacific Daylight Time, subtract seven hours.

LATITUDE: North latitude, in degrees and minutes, of the earthquake epicenter.

LONGITUDE: West longitude, in degrees and minutes, of the earthquake epicenter.

DEPTH: $\quad$ The depth of the earthquake in kilometers $(\mathrm{km})$.

MAG: $\quad$ The magnitude is expressed as Coda-Length magnitude $M_{c}$, an estimate of local magnitude $\mathrm{M}_{\mathrm{L}}$ (Richter 1958). If Magnitude is blank no determination could be made.

NS/NP: $\quad$ Number of stations/number of phases used in the solutions.

GAP: Azimuthal gap. The largest angle (relative to the epicenter) containing no stations.

DMIN: The distance from the earthquake epicenter to the closest station

RMS: $\quad$ The root-mean-square residual (observed arrival times minus the predicted arrival times) at all stations used to locate the earthquake. It is only useful as a measure of quality of the solution when five or more well-distributed stations are used in the solution. Good solutions are normally characterized by RMS values of less than about 0.3 seconds.

Q: $\quad$ The Quality Factors indicate the general reliability of the solution/location (A is best quality, D is worst). See Section 3.3 of this report: Quality Factors.

TYPE: $\quad P$ is Probable Blast; $X$ is Confirmed Blast; $F$ is Felt Earthquake; $H$ is hand picked from helicorder; $\mathrm{S}$ is surficial event (rockslide, avalanche) and not a explosion or tectonic earthquake; blank is local earthquake. 


\subsection{Geology and Tectonic Analysis}

\subsection{Earthquake Stratigraphy}

Studies of seismicity at the Hanford Site have shown that the seismicity is related to crustal stratigraphy (layers of rock types) (Rohay et al. 1985; DOE 1988). The main geologic units at Hanford and the surrounding area are:

- The Miocene Columbia River Basalt Group (CRBG)

- The Paleocene, Eocene, and Oligocene sediments

- The crystalline basement (Precambrian and Paleozoic craton; Mesozoic accreted terranes).

\subsubsection{Geologic Structure Beneath the Monitored Area}

Between the late 1950s and the early 1980 s, deep boreholes were drilled for hydrocarbon exploration in the Columbia Basin. These boreholes provided accurate measurements of the physical properties of the CRBG and the pre-basalt sediments (Reidel et al. 1994, 1998), but the thickness of the pre-basalt sediments and nature of the crystalline basement are still poorly understood. The difference between the thickness listed in Table 7 and the thickness of the crustal layers in the velocity model in Table 9 reflect data specific to the University of Washington's crustal velocity model for eastern Washington. Table 9 is derived from Figure 4 and was developed for the geologic interpretation in Section 4.0 of this report. Figure 4 shows north-south and east-west cross sections through the Columbia Basin based on surface mapping, deep boreholes, geophysical data (including the work of Rohay et al. [1985]), and magnetotelluric data obtained as part of BWIP (DOE 1988). The thickness of these units are highly variable across the monitored area. Table 9 summarizes the approximate thickness at the borders of the monitored area.

Table 9. Thickness of Stratigraphic Units Across the Monitoring Area

\begin{tabular}{|l|l|l|l|l|}
\hline \multicolumn{1}{|c|}{ Stratigraphy } & \multicolumn{1}{c|}{ North } & \multicolumn{1}{c|}{ South } & \multicolumn{1}{c|}{ East } & \multicolumn{1}{c|}{ West } \\
\hline $\begin{array}{l}\text { Columbia River Basalt Group (includes } \\
\text { suprabasalt sediments) }\end{array}$ & $3.0 \mathrm{~km}$ & $4.5 \mathrm{~km}$ & $2.2 \mathrm{~km}$ & $4.2 \mathrm{~km}$ \\
\hline Pre-basalt Sediments & $3.0 \mathrm{~km}$ & $>4.5 \mathrm{~km}$ & .0 & $>6.0 \mathrm{~km}$ \\
\hline
\end{tabular}




\section{Yakima Fold Belt}

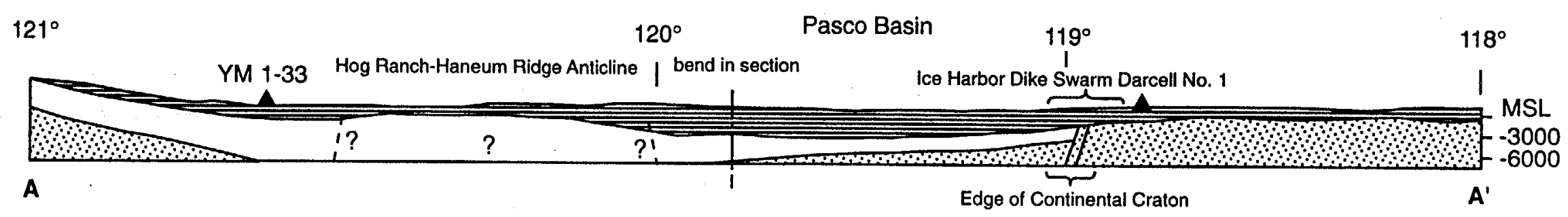

$\stackrel{A}{i}$
Palouse Slope
NO VEATICAL EXAGGERATION

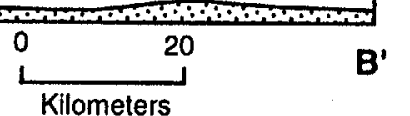

No'
NO

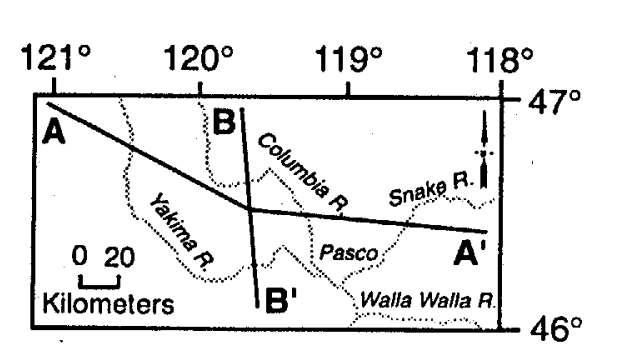

A Hydrocarbon exploration borehole

Columbia River Basalt Group $\square$ Tertiary sediments
Basement rock

Figure 4. Geologic Cross Sections Through the Columbia Basin 
The thickness of the basalt and the pre-basalt sediments varies as a result of different tectonic environments. The western edge of the North American craton (late Precambrian/Paleozoic continental margin and Precambrian craton) is located in the eastern portion of the monitored area. The stratigraphy on the craton consists of CRBG overlying crystalline basement; the crystalline basement is continental crustal rocks that underlie much of the western North America. The stratigraphy west of the craton consists of $4-5 \mathrm{~km}$ of CRBG overlying greater than $6 \mathrm{~km}$ of pre-basalt sediments. This in turn overlies accreted terranes of Mesozoic age. The area west of the craton was subsiding during the Eocene and Oligocene, accumulating great thickness of pre-CRBG sediments. Continued subsidence in this area during the Miocene resulted in thicker CRBG compared to that on the craton. Subsidence continues today but at a greatly reduced rate (Reidel et al. 1994).

\subsubsection{Depth of Earthquakes}

Since records have been kept, about 75 percent of the earthquakes at the Hanford Site have originated in the CRBG layer. The pre-basalt sediments have had about 7 percent of the events and the crystalline basement has had 18 percent. Seismic events recorded for the first quarter of FY99 are listed in Table 10.

Table 10. Number of Local Earthquakes Occurring in Stratigraphic Units

\begin{tabular}{|l|c|c|c|c|c||}
\hline \multicolumn{1}{|c|}{ Unit } & First Quarter & Second Quarter & Third Quarter & Fourth Quarter & FY 1999 \\
\hline \hline Basalt & 7 & - & - & - & 7 \\
\hline Pre-basalt Sediments & 0 & - & - & - & 0 \\
\hline Crystalline Basement & 7 & - & - & - & 7 \\
\hline Total & 14 & - & - & - & 14 \\
\hline
\end{tabular}

\subsection{Tectonic Pattern}

Studies at the Hanford Site have concluded that earthquakes that can affect the Hanford Site can occur in the following six different tectonic environments (earthquake sources) at the Hanford Site (Geomatrix 1996).

- Reverse/thrust faults. Reverse/thrust faults in the CRBG associated with major anticlinal ridges such as Rattlesnake Mountain, Yakima Ridge, and Umtanum Ridge could produce some of the largest earthquakes.

- Secondary faults. These are associated with the major anticlinal ridges.

- Swarm areas. Small geographic areas of unknown geologic structure produce clusters of events (swarms), usually in the CRBG in synclinal valleys. These clusters consist of a series of small shocks with no outstanding principal event. Swarms occur over a period of days or months and the events may number into the hundreds and then quit, only to start again at a later date. This differs from the sequence of foreshocks, mainshock, and trailing-off aftershocks that have the same epicenter or are associated with the same fault system. Three principal swarm areas are known at the Hanford Site. 
One is the Wooded Island Swarm Area along the Columbia River near the 300 Area. The second area, the Coyote Rapids Swarm Area, extends from the vicinity of the $100 \mathrm{~K}$ Area north-northeast along the Columbia River Horn to the vicinity of the $100 \mathrm{~N}$ Area. The third major swarm area is along the Saddle Mountains on the northern boundary of the Hanford Site. Other earthquake swarm areas are present, but activity is less frequent.

- The entire Columbia Basin. The entire basin, including the Hanford Site, could produce a "floating" earthquake. A floating earthquake is one that, for seismic design purposes, can happen anywhere in a tectonic province and is not associated with any known geologic structure. It is classified as a random event by Seismic Monitoring for purposes of seismic design and vibratory ground motion studies.

- Basement source structures. Studies (Geomatrix 1996) suggest that major earthquakes can originate in tectonic structures in the crystalline basement. Because little is known about geologic structures in the crystalline basement beneath the Hanford Site, earthquakes cannot be directly tied to a mapped fault. Earthquakes occurring in the crystalline basement without known sources are treated as random events for seismic hazards analysis and seismic design.

- The Cascadia Subduction Zone. This source recently has been postulated to be capable of producing a magnitude 9 earthquake. Because this source is along the western boundary of Washington State and outside the HSN, the Cascadia Subduction Zone is not an earthquake source that is monitored at the Hanford Site, so subduction zone earthquakes are not reported here. Because any earthquake along the Cascadia Subduction zone can have a significant impact on the Hanford Site (Geomatrix 1996), the University of Washington monitors and reports on this earthquake source for the U.S. Department of Energy (DOE). Ground motion from any moderate or larger Cascadia Subduction Zone earthquake is detected by seismometers in the HSN.

\subsection{Current Tectonic Activity}

The locations for events that occurred in the first quarter of FY99 are summarized in Table 10 and Figures 5 and 6 . These events are summarized in the following sections.

\subsubsection{First Quarter of FY 1999}

The locations of all events with $M_{c}$ greater than 0.5 that occurred between October 1,1998 and December 31, 1998 are shown on Figure 5. The locations of all seismic events detected from October 1, 1997 to September 30,1998 are shown in Figure 6. Figure 7 is a tectonic map of the Yakima Fold Belt and Hanford Site. The Yakima Fold Belt is the main tectonic province of concern for the Hanford Site. The figure shows the major mapped ridges and faults that are potential seismic sources. These figures should be referred to for the following discussions. 


\subsubsection{Major Anticlinal Ridges}

During the reporting period, no seismic events occurred along any major ridge.

\subsubsection{Secondary Geologic Structures}

On October 16, 1998, one earthquake occurred along the Horn Rapids anticline. The Horn Rapids anticline is a generally north trending anticline that is responsible for the "horn" or wide arc that the Yakima River takes between Benton City, Washington and West Richland, Washington. This earthquake was located along the east flank in the flood plain of the Yakima River but can not be linked to any specific fault. Because it occurs on the flank of the anticline and it occurred in the basalt, this event is classified as an earthquake associated with a secondary geologic structure.

\subsubsection{Swarm Area Activity}

During the reporting period, 7 events $(50 \%)$ were located in earthquake swarm areas.

\subsubsection{Saddle Mountains Swarm Area}

There was 1 event (7\%) in the Saddle Mountains swarm area on December 3, 1998. It was a small event $\left(0.9 \mathrm{M}_{\mathrm{c}}\right)$ that occurred in the CRBG north of the Saddle Mountains thrust fault on the Royal Slope.

\subsubsection{Wooded-Island Swarm Area}

No events occurred in the Wooded Island swarm during the first quarter of FY99.

\subsubsection{Coyote Rapids Swarm Area}

No events occurred in the Coyote Rapids swarm during the first quarter of FY99.

\subsubsection{Other Swarm Areas}

On November $22^{\text {nd }}$ five small $\left(\leq 1 \mathrm{M}_{\mathrm{c}}\right)$ events occurred in the CRBG on the Wahluke slope east of the Hanford Site. A sixth event occurred several miles west of the five events on November $25^{\text {th }}$. The sixth event was very small $\left(\mathrm{M}_{c}=0.5\right)$ so the location may be poorly constrained. These events occurred on the Palouse Slope where there are no known structures. They occurred in the same area as a previously active earthquake swarm area south of Othello, Washington (DOE 1988). The area was active from the beginning of seismic monitoring at Hanford (ca 1970) but there has been practically no activity from 1985 to the present.

\subsubsection{Random or Floating Events}

There were 6 events (43\%) that are classified as random events this quarter because they did not occur in a known earthquake swarm area or along a known geologic structure. 
On October 30, 1998 a small event $\left(<1 \mathrm{M}_{\mathrm{c}}\right)$ occurred in the crystalline basement east of the Hanford Site near Eltopia, Washington. Because of its great depth, location in the craton, and absence of known geologic structures near this location, it is classified as a random earthquake.

Five small $\left(<2 \mathrm{M}_{c}\right)$ events occurred between November $16^{\text {th }}$ and November $24^{\text {th }}$ in the Prosser, Washington area. Three of the events occurred between November $16^{\text {th }}$ and $17^{\text {th }}$. Because of their great depth and the absence of known geologic structures near this location, these events are classified as random earthquakes.

Table 11. Summary of Earthquake Locations

\begin{tabular}{|l|l|c|c|c|c|c|}
\hline \multicolumn{2}{|l|}{} & $\begin{array}{c}\text { First } \\
\text { Quarter }\end{array}$ & $\begin{array}{c}\text { Second } \\
\text { Quarter }\end{array}$ & $\begin{array}{c}\text { Third } \\
\text { Quarter }\end{array}$ & $\begin{array}{c}\text { Fourth } \\
\text { Quarter }\end{array}$ & FY 1999 \\
\hline \hline $\begin{array}{l}\text { Major Structures along anticlinal } \\
\text { Ridges }\end{array}$ & 1 & - & - & - & 1 \\
\hline \multirow{4}{*}{$\begin{array}{l}\text { Swarm } \\
\text { Areas }\end{array}$} & Saddle Mountains & 1 & - & - & - & 1 \\
\cline { 2 - 7 } & Coyote Rapids & 0 & - & - & - & 0 \\
\cline { 2 - 7 } & Wooded Island & 0 & - & - & - & 0 \\
\cline { 2 - 7 } & Other & 6 & - & - & - & 6 \\
\hline \multicolumn{2}{|l|}{ Random Events } & 6 & - & - & - & 6 \\
\hline
\end{tabular}




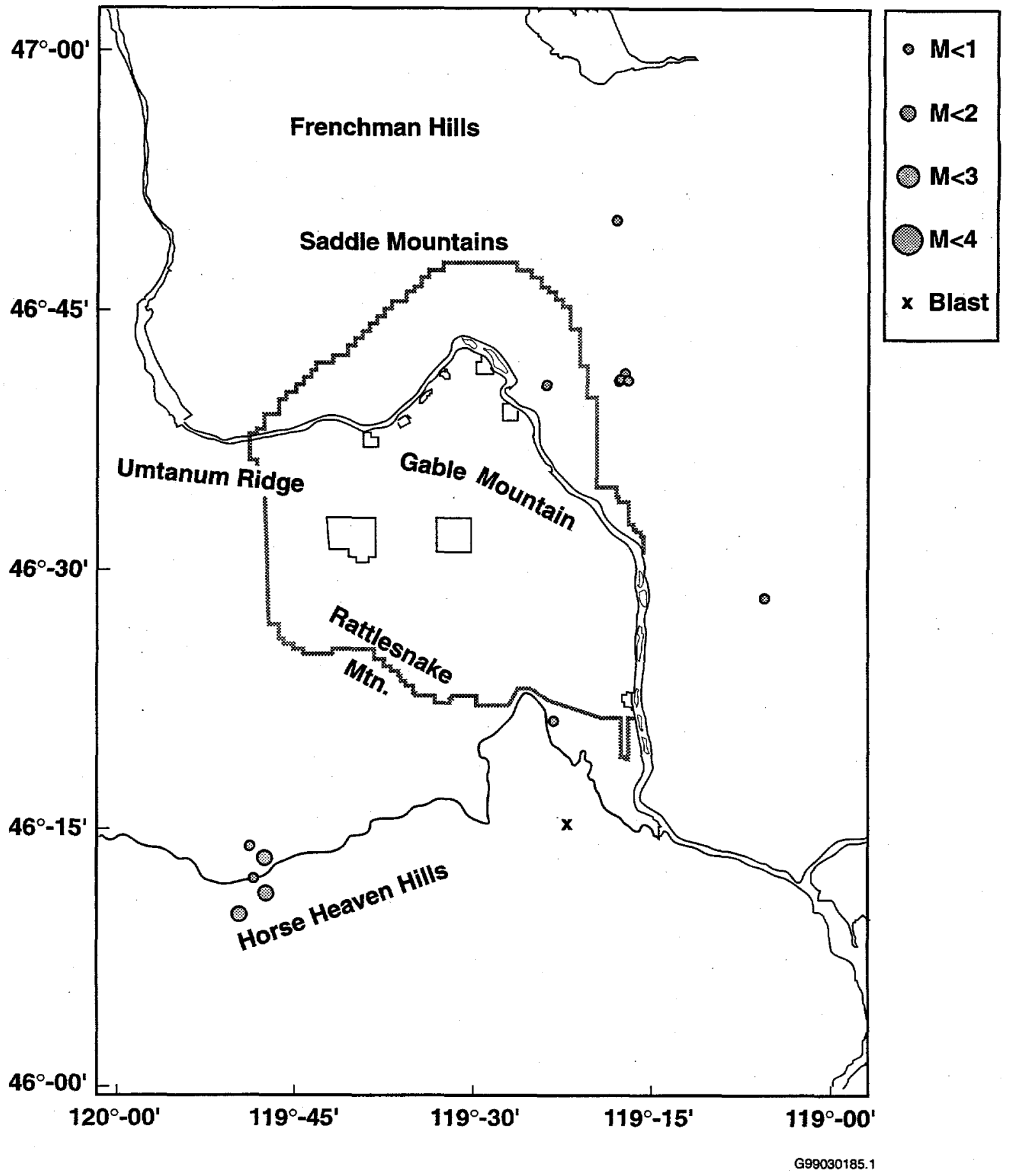

Figure 5. Locations of All Events Between October 1, 1998 and December 31, 1998. (Coda Length Magnitude $\left(\mathrm{M}_{\mathrm{c}}\right)$ scale is shown at the side of the map.) 

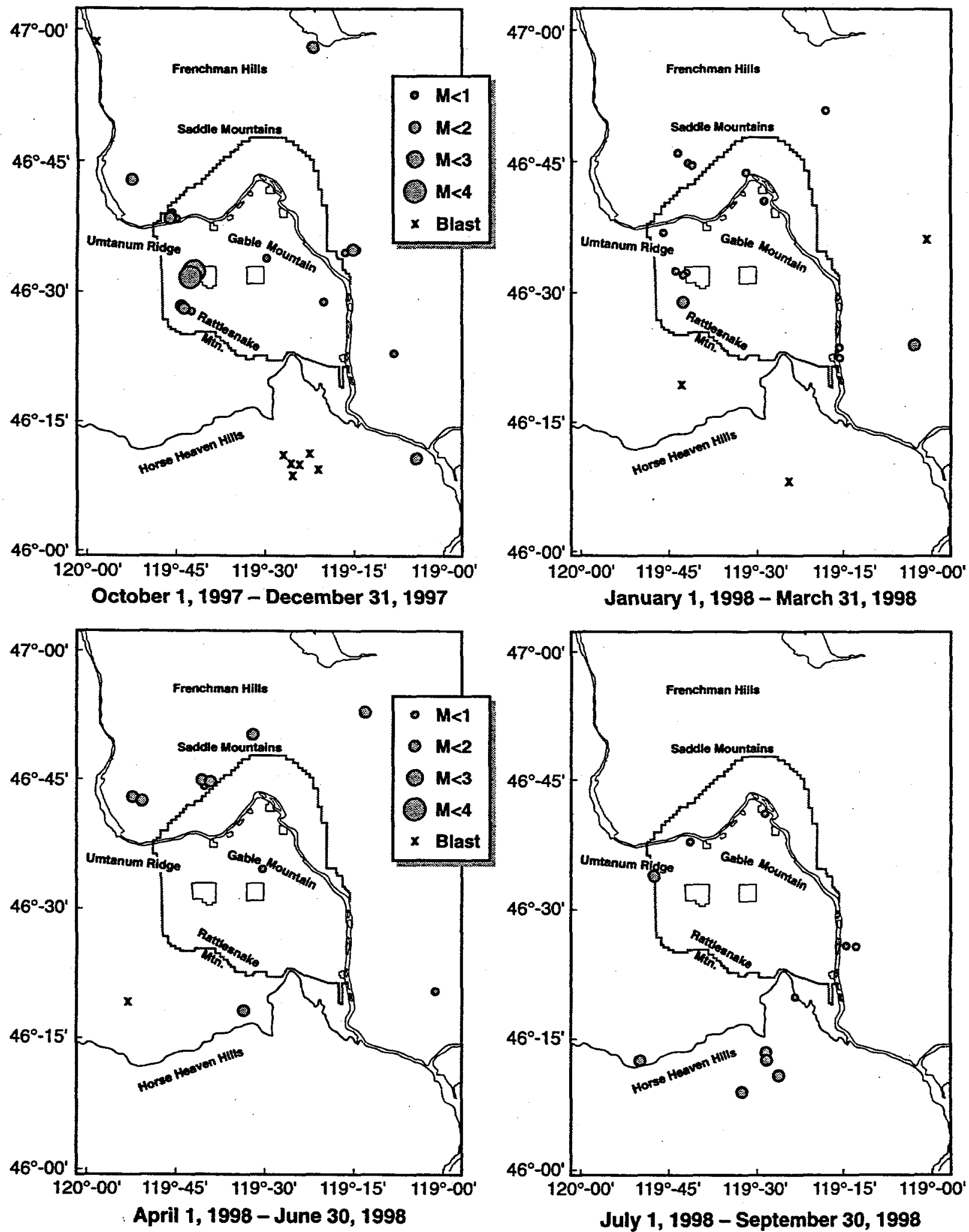

RP98120046.1

Figure 6. All Located Earthquakes Grouped by Quarter for FY99. (a) First Quarter (October 1, 1998 December 31, 1998; (b) January 1, 1999 - March 31, 1999; (c) April 1, 1999 - June 30, 1999; (d) July 1, 1999 - September 30, 1999. (Coda Length Magnitude $\left(\mathrm{M}_{c}\right)$ scale is shown at the side of the map.) 


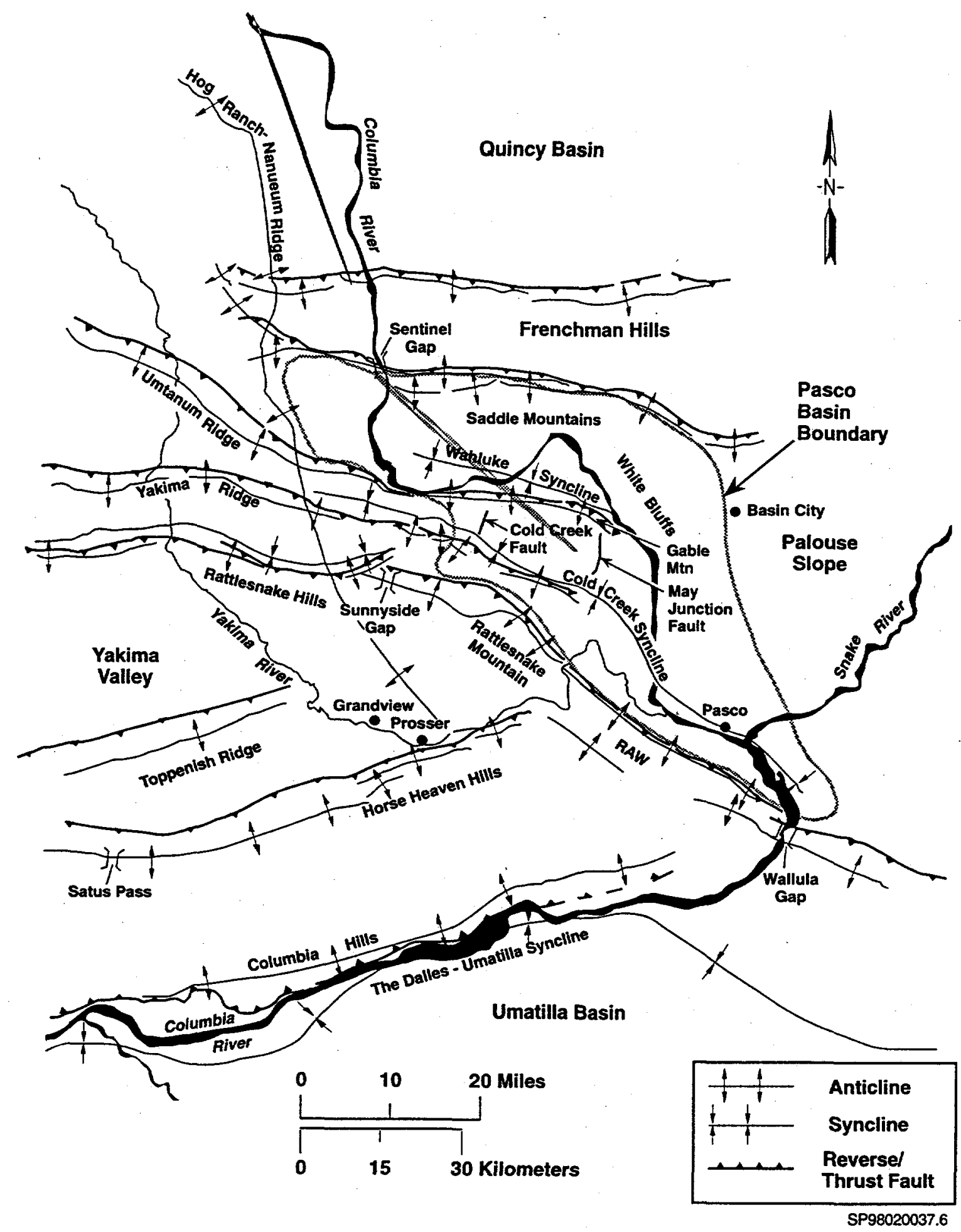

Figure 7. Structural and Tectonic Map of Columbia Basin Showing Major Seismic Source Structures 


\subsection{Strong Motion Accelerometer Operations: May 1997 to September 30, 1997}

The Hanford Strong Motion Accelerometer network came back on line November 20, 1999. During the nearly 1 month of operating during the first quarter there were no triggers resulting from an earthquake. The Strong Motion Accelerometer network had several triggers resulting from noise. During FY 2000 the amount of triggers resulting from noise and normal human activity will be monitored to determine the optimal settings for the triggering system. An optimum balance between having minimal triggers caused by noise and detection of the smallest possible earthquake is sought. 


\subsection{Capabilities in the Event of a Significant Earthquake}

The strong motion accelerometer network was installed to comply with requirements contained in U.S. DOE Order 5480.28, Natural Phenomena Hazards Mitigation. The SMA network was designed to provide ground motion in areas at Hanford that have high densities of people and/or have hazardous facilities. This section summarizes the capabilities of the Seismic Monitoring Team using the Hanford Strong Motion Accelerometer Network in the event of an earthquake at Hanford.

\subsection{Use of the SMA Network in the Event of an Earthquake}

Historically only a few Hanford sites had instruments to provide data on peak ground accelerations or any type of ground motion at Hanford. The SMA instruments were located so that if an earthquake occurred, ground motion data would be readily available to assess the damage at the $100 \mathrm{~K}$ Area, the 200 East and West Areas, the 300 and 400 Area facilities which have the greatest concentration of people and all the hazardous materials.

Facilities at Hanford have undergone various degrees of seismic analysis either during design or during re-qualification. Although the seismic design of a building may be known, when an earthquake is felt a determination must be made as to the extent of damage before it can be reoccupied and the systems restarted. A felt earthquake may not cause any damage to a building but without adequate characterization of the ground motion, initial determination of damage may be impossible.

In the event of an earthquake building managers, emergency directors, and engineers can obtain ground motion data recorded by the SMA network from the Office of Seismic Monitoring. If a SMA is triggered, the Office of Seismic Monitoring will download events that were recorded and determine the peak ground accelerations and the spectral response curves. This information can then be used by the facility engineers to determine if the ground motion exceeded, is equal to, or is less than the building design. This, together with assessments from trained engineers, allows the facility manager to make a rapid and cost effective determination on whether a building is safe to reoccupy or should be not be used until it has be inspected in more detail. Buildings that have designs exceeding the recorded ground motion could be put back into service very quickly; building that are very close to or less than measured ground motion could be given priority for on site damage inspections. 


\subsection{References}

Crosson, R. S. 1972. Small Earthquakes, Structure and Tectonics of the Puget Sound Region, Bulletin of the Seismological Society of America, v. 62, no. 5, pp. 1133-1171.

DOE. 1988. Site Characterization Plan for the Reference Location, Hanford, Washington-Consultation Draft, Report DOE/RW-0164, Vol. 1, U.S. Department of Energy, Washington, D.C.

Geomatrix. 1996. Probabilistic Seismic Hazard Analysis, DOE Hanford Site, Washington, WHC-SDW236A-TI-002, Rev. 1, Westinghouse Hanford Company, Richland, Washington.

Hartshorn, D. C., S. P. Reidel, and A. C. Rohay. 1998a. Hanford Annual First Quarter Seismic Report, Fiscal Year 1998: Seismicity on and Near the Hanford Site, Pasco Basin, Washington, Pacific Northwest National Laboratory Report PNNL-11557-5.

Hartshorn, D. C., S. P. Reidel, and A. C. Rohay. 1998b. Hanford Annual Second Quarter Seismic Report, Fiscal Year 1998: Seismicity on and Near the Hanford Site, Pasco Basin, Washington, Pacific Northwest National Laboratory Report PNNL-11557-7.

Hartshorn, D. C., S. P. Reidel, and A. C. Rohay. 1998c. Hanford Annual Third Quarter Seismic Report 98C, Fiscal Year 1998: Seismicity on and Near the Hanford Site, Pasco Basin, Washington: April 1, 1998 Through June 30, 1998, Pacific Northwest National Laboratory Report PNNL-11557-8.

Moore, Carlton, and S. P. Reidel, 1996, Hanford Site Seismic Monitoring Instrumentation Plan, Westinghouse Hanford Company Report WHC-SD-GN-ER-30036.

Reidel, S. P., N. P. Campbell, K. R. Fecht, and K. A. Lindsey. 1994. Late Cenozoic Structure and Stratigraphy of South-Central Washington, in Cheney, E. and R. Lasmanis, Eds., Regional Geology of Washington State, Washington Division of Geology and Earth Resources Bulletin 80, pp 159-180, Olympia, Washington.

Reidel, S. P., K. R. Fecht, M. C. Hagood, and T. L. Tolan. 1989. Geologic Development of the Central Columbia Plateau, in Reidel, S. P. and P. R. Hooper, Eds., Volcanism and Tectonism in the Columbia River Flood-Basalt Province Geological Society of America Special Paper 239, pp. 247-264.

Richter, C. F. 1958. Elementary Seismology, W. H. Freeman and Company, p. 768.

Rohay, A. C., D. W. Glover, and S. D. Malone. 1985. Time-term Analysis of Upper Crustal Structure in the Columbia Basin, Washington: Report RHO-BW-SA-435 P, Rockwell Hanford Operations, Richland, Washington. 


\section{Distribution}

No. of

Copies

ONSITE

6 U.S. Department of Energy, Richland Operations Office

M. J. Furman

R. D. Hildebrand

J. E. Mecca

M. R. Moreno

K. M. Thompson

J. L. Tokarz-Hames

2 Bechtel Hanford, Inc.

K. R. Fecht

P. J. Mackey

B \& W

D. A. Conners
$\mathrm{H} 0-12$

H0-12

R3-79

A5-55

H0-12

A5-55

$\mathrm{H} 0-02$

B3-15

2 Duke Engineering Services Hanford

R. Whitehurst

M. K. Mahaffey

DynCorp Tri-Cities Services, Inc.

T. P. Morales
No. of

Copies

2 Fluor Daniels Hanford

J. T. Curtis

B3-15

S. M. Faulk

L4-14

Lockheed Martin Hanford

R. R. Thompson

R2-12

Numatec Hanford

T. J. Conrads

H5-25

2 Rust Federal Services

M. I. Wood

H6-06

M. T. York

T3-01

\section{Pacific Northwest National Laboratory}

M. V. Berriochoa

K9-56

D. C. Hartshorn (15)

K6-81

G. R. Holdren

K6-81

S. P. Reidel

K6-81

R. M. Smith

K6-96

D. A. Varley (7)

K1-06 